\title{
Kecacingan, malaria, dan status besi ibu hamil di Kabupaten Batang Hari Provinsi Jambi
}

\author{
Helfiyan ${ }^{1}$, Hamam Hadi², Siti Helmyati ${ }^{3}$
}

\begin{abstract}
Background: Anemia among pregnant women may increase abortion, premature, low birth weight and even mortality before and after delivery. Factors causing anemia in Indonesia are lack of Fe, inadequate intake, demanding needs, and lack of nutrient facilitating Fe absorption. Besides, infection such as worm and malaria may cause anemia as well. Result of household health survey 2001 stated that prevalence of pregnant women with anemia was $40 \%$ in Indonesia. In Jambi Province, it was 39\% in 2003 and $42.3 \%$ for Batang Hari Regency while infection of malaria was 50.0\% in all age groups and many other districts that its environment were woods, humid, and wasted that may increase infection of hookworm. Objective: The study was proposed to know the correlation of hookworm, malaria with anemia among pregnant women by analyzing correlation of hookworm, malaria, and anemia and correlation of hookworm, malaria and Fe status among pregnant women.

Method: This was cross sectional study. It held from September until December 2005 in Batang Hari Regency, Jambi Province. Subjects were 132 pregnant women. Examination of blood for Hb, malaria and ferritin were taken together while feces were later.

Results: There were no significant correlation of Ascaris lumbricoides infection with anemia $(p=0.36 ; 0 R=2.43)$, Trichiuris thrichiura infection with anemia $(p=0.30)$, 2 kinds of worm Ascaris lumbricoides + Trichiuris trichiura with anemia $(p=0.08 ; O R=4.87)$, and infection of Ascaris lumbricoides + Necator americanus with anemia $(p=0.30)$. There was significant correlation of 3 kinds of worm Ascaris lumbricoides + Trichiuris trichiura + Necator americanus with anemia ( $p=0.018$; OR = 7.3). There were no significant correlation of Ascaris lumbricoides with ferritin $(p=0.17 ;$ OR $=$ 3.23) and Trichiuris trichiura with ferritin $(p=0.25)$. There was significant correlation of 2 kinds of worm Ascaris lumbricoides + Trichiuris trichiura with ferritin $(p=0.04 ; O R=6.4)$. There was no significant correlation of Ascaris lumbricoides + Necator americanus with ferritin $p=0.25$. There were significant correlation of 3 kinds of worm (Ascaris lumbricoides + Trichiuris trichiura + Necator americanus) with ferritin $p=0.007 ;$ OR $=9.69$ and ferritin with anemia $p=0.0001 ; 0 R=17.45$.

Conclusion: There was no significant correlation of hookworms Ascaris lumbricoides, Trichiuris trichiura, Ascaris lumbricoides + Trichius trichiura, Ascaris lumbricoides + Necator americanus with anemia. There were significant correlation of infection of Ascaris lumbricoides + Trichiuris trichiura + Necator americanus with anemia and malaria with anemia. There was no correlation of hookworms Ascaris lumbricoides, Trichiuris trichiura, Ascaris lumbricoides + Necator americanus with anemia. There were correlation of infection Ascaris lumbricoides + Trichiuris trichiura and Ascaris lumbricoides + Trichiuris trichiuris + Necator americanus with ferritin, malaria with ferritin, and ferritin with anemia.
\end{abstract}

KEY WORDS hookworm, malaria, ferritin, anemia

\section{PENDAHULUAN}

Anemia karena kekurangan besi merupakan salah satu masalah kesehatan utama di Indonesia. Salah satu kelompok masyarakat yang rawan menderita anemia gizi adalah wanita usia subur (WUS) termasuk ibu hamil $(1,2)$.

Anemia gizi besi (AGB) terutama banyak diderita oleh wanita hamil, wanita menyusui, dan WUS pada umumnya, karena fungsi kodrati. Peristiwa kodrati wanita adalah haid, melahirkan, dan menyusui yang menyebabkan kebutuhan $\mathrm{Fe}$ atau zat besi relatif lebih tinggi dibandingkan kelompok lain (3). Anemia gizi merupakan masalah kesehatan yang berperan dalam penyebab tingginya angka kematian ibu dan bayi, produktivitas kerja yang rendah, kemampuan belajar, serta prestasi belajar $(4,5)$.

Anemia pada ibu hamil akan sangat berpengaruh terhadap kualitas manusia yang akan dilahirkan dan kualitas sumber daya manusia (SDM) generasi yang akan datang (1). Selain itu, anemia pada ibu hamil dapat meningkatkan kejadian abor- tus, prematur, berat badan lahir rendah (BBLR), serta dapat menyebabkan kematian pada ibu hamil pada waktu dan sesudah melahirkan (6).

Penyebab anemia yang banyak ditemukan di Indonesia adalah anemia akibat kekurangan zat besi, baik karena asupan melalui konsumsi makanan yang masih kurang, kebutuhan yang meningkat, maupun kurangnya konsumsi pemacu penyerapan zat besi seperti protein hewani dan vitamin $\mathrm{C}$. Selain itu, penyebab anemia lainnya antara lain karena parasit kecacingan, infeksi malaria, dan tuberkulosis (7).

\footnotetext{
1 Dinas Kesehatan Provinsi Jambi, Jl. RM Noer Atmadibrata No 8, Telanaipura, Jambi

2 Magister Gizi Kesehatan UGM, JI Farmako, Sekip Utara, Yogyakarta 55281, e-mail: hamam@indosat.net.id

3 Program Studi Gizi Kesehatan UGM, Jl. Farmako, Sekip Utara, Yogyakarta
} 55281, e-mail: siti_helmyati@yahoo.com 
Risiko anemia pada ibu hamil akan meningkat dua kali lebih besar bila disertai parasit malaria dalam darah (8). Husaini (9) mengemukakan bahwa pada daerah tertentu anemia gizi diperberat oleh adanya infeksi cacing pada usus yang akan menyebabkan pendarahan di usus.

Salah satu penyakit parasit di Indonesia yang menjadi masalah kesehatan masyarakat disebabkan oleh cacing usus yang ditularkan melalui tanah. Pada tahun 1990 dinyatakan 44 juta dari 124 juta wanita hamil terinfeksi cacing tambang. Gangguan gastrointestinal, malabsorbsi, dan gangguan pengecap memperburuk status besi, seng, serta energi protein, dan anemia pada ibu hamil (8).

Torlesse et al. cit. Stekette (8) menyatakan bahwa kekurangan zat gizi mikro dan anemia pada sakit malaria, malnutrisi, dan infeksi parasit (cacing), infeksi dan imunitas berhubungan dengan kejadian protein energy malnutrition (PEM), defisiensi mikronutrien, dan penyakit infeksi. Wanita hamil, kekurangan mikronutrien meningkatkan risiko infeksi parasit dan infeksi malaria.

Berdasarkan hasil survei kesehatan rumah tangga (SKRT) di Indonesia tahun 2001, prevalensi ibu hamil anemia sebesar $40 \%$ (1), sedangkan berdasarkan hasil survei anemia pada ibu hamil di Provinsi Jambi tahun 2003 prevalensi tersebut sebesar $39 \%$, sedangkan khusus di Kabupaten Batang Hari sebesar 42,3\% (10). Kabupaten Batang Hari merupakan salah satu daerah endemis malaria. Berdasarkan Profil Dinas Kesehatan Kabupaten Batang Hari, diperoleh angka kejadian malaria pada semua kelompok usia sebesar 11.171 orang $(10,05 \%)$ dari 210.561 jumlah penduduk Kabupaten Batang Hari tahun 2004 (11). Secara geografis, sebagian besar penduduk Kabupaten Batang Hari bermukim di dekat hutan dengan tanah tempat tinggal yang lembab. Hal ini merupakan salah satu media pendukung berkembangbiaknya cacing dan nyamuk yang merupakan salah satu faktor risiko terjadinya penyakit infeksi seperti kecacingan dan malaria.

Tujuan penelitian ini secara umum adalah mengetahui hubungan antara kecacingan, malaria, dan status besi terhadap kejadian anemia pada ibu hamil di Kabupaten Batang Hari Provinsi Jambi.

\section{BAHAN DAN METODE}

Penelitian ini merupakan penelitian observasional dengan rancangan cross sectional. Penelitian dilaksanakan pada bulan September sampai dengan Desember 2005 di Kabupaten Batang Hari, Provinsi Jambi.

Subjek penelitian ini meliputi ibu hamil di Kabupaten Batang Hari yang memenuhi kriteria inklusi dan eksklusi. Kriteria inklusi meliputi: usia kehamilan di atas 12 minggu, bertempat tinggal di wilayah Kabupaten Batang Hari, dan bersedia menjadi responden penelitian. Kriteria eksklusi adalah ibu hamil yang termasuk dalam risiko tinggi. Subjek dipilih secara simple random sampling dan diperoleh sebanyak 132 orang ibu hamil dengan usia kehamilan memasuki tri- mester II berdasarkan rumus proporsi populasi untuk satu sampel menggunakan tingkat kemaknaan $Z \alpha=1,96$ (tingkat kepercayaan 95\%), $d=0,085$, dan $P=0,423$ (12).

Karakteristik ibu hamil dikumpulkan menggunakan kuisioner, hemoglobin dengan pemeriksaan menggunakan metode cyanmethoglobin, kecacingan dengan metode Kato Katz, malaria dengan metode Giemsa, dan feritin dengan metode enzim linked fluoresin immuno assay (ELFA). Data kemudian dianalisis menggunakan Fisher's exact test.

\section{HASIL}

\section{Karakteristik subjek penelitian}

Karakteristik ibu hamil dan keadaan sosial ekonomi ibu hamil dapat dilihat pada Tabel 1. Dari tabel tersebut diketahui sebagian besar subjek $(70,5 \%)$ berusia antara 20-35 tahun (tergolong WUS yang dianjurkan untuk hamil) dengan jarak kehamilan sebagian besar subjek $(79,3 \%)$ lebih dari 3 tahun. Sebanyak $25,8 \%$ subjek memeriksakan kehamilan kurang dari 2 kali pada trimester II dan sebanyak $31,1 \%$ subjek yang memeriksakan kehamilannya lebih dari 4 kali pada trimester III. Sebanyak $68,9 \%$ ibu hamil memiliki anggota keluarga dengan jumlah kurang dari 4 orang dan sebagian besar ibu hamil $(90,1 \%)$ berstatus gizi baik yang ditunjukkan dengan dengan ukuran LILA (lingkar lengan atas) normal.

Dilihat dari tingkat sosial ekonomi ibu hamil, sebagian besar (56\%) memiliki tingkat pendidikan terakhir SD (sekolah dasar) sampai SLTP (sekolah lanjutan tingkat pertama), sedangkan sebanyak $54,5 \%$ suami memiliki tingkat pendidikan akhir SLTA (sekolah lanjutan tingkat atas). Ibu hamil sebagian besar $(67,4 \%)$ adalah ibu rumah tangga dan sebanyak $51,7 \%$ suami memiliki status sebagai karyawan swasta/wiraswasta dengan pendapatan keluarga sebagian besar $(58,8 \%)$ sudah di atas rata-rata UMR (upah minimum regional) yaitu berada pada rentang $\mathrm{Rp} 400.000,--\mathrm{Rp}$ 1.000.000,- per bulan.

\section{Hubungan antara kecacingan dengan anemia ibu hamil}

Ibu hamil yang terkena infeksi kecacingan berdasarkan jenis cacing dapat dilihat pada Tabel 2. Berdasarkan hasil analisis bivariat di atas, diketahui tidak ada hubungan yang bermakna antara infeksi cacing Ascaris lumbricoides dengan anemia ibu hamil $(p=0,36)$, begitu pula hubungan antara infeksi cacing Trichiuris trichiura dengan anemia ibu hamil ( $p$ =0,30). Ibu hamil yang terinfeksi cacing Ascaris lumbricoides dan Trichiuris trichiura dengan anemia masing-masing berjumlah 3 orang (50\%) dan 1 orang (100\%).

Hubungan yang tidak bermakna juga ditemukan antara infeksi 2 jenis cacing Ascaris lumbricoides + Trichiuris trichiura dan Ascaris lumbricoides + Necator americanus dengan anemia ibu hamil, dengan nilai p masing-masing 0,08 dan 0,30. Jumlah ibu hamil yang dinyatakan positif mengalami infeksi 2 
TABEL 1. Karakteristik subjek penelitian

\begin{tabular}{|c|c|c|}
\hline Karakteristik & $\mathbf{n}$ & $\%$ \\
\hline \multicolumn{3}{|l|}{ Usia ibu (tahun) } \\
\hline$<20$ & 10 & 7,65 \\
\hline $20-35$ & 93 & 70,5 \\
\hline$\geq 35$ & 29 & 21,9 \\
\hline \multicolumn{3}{|l|}{ Usia hamil (minggu) } \\
\hline $13-24$ & 67 & 50,8 \\
\hline $25-36$ & 65 & 49,2 \\
\hline \multicolumn{3}{|l|}{ Jarak kehamilan (tahun) } \\
\hline$<3$ & 19 & 20,7 \\
\hline$>3$ & 73 & 79,3 \\
\hline \multicolumn{3}{|l|}{ Paritas (kali) } \\
\hline$<3$ & 78 & 59,1 \\
\hline$>3$ & 54 & 40,9 \\
\hline \multicolumn{3}{|l|}{ Periksa kehamilan trimester II (kali) } \\
\hline$<2$ & 34 & 25.8 \\
\hline$>2$ & 32 & 24,2 \\
\hline \multicolumn{3}{|l|}{ Periksa kehamilan trimester III (kali) } \\
\hline$<4$ & 24 & 18,2 \\
\hline$\geq 4$ & 42 & 31,8 \\
\hline \multicolumn{3}{|l|}{ Jumlah anggota keluarga (orang) } \\
\hline$\leq 4$ & 91 & 68,9 \\
\hline$>4$ & 41 & 31,1 \\
\hline \multicolumn{3}{|l|}{ LILA (lingkar lengan atas) } \\
\hline Risiko KEK (kekurangan energi kronis) & 13 & 9,9 \\
\hline Normal & 119 & 90.1 \\
\hline \multicolumn{3}{|l|}{ Pendidikan ibu } \\
\hline Pendidikan dasar $\quad(S D+S L T P)$ & 74 & 56,0 \\
\hline Pendidikan lanjut (SLTA ke atas) & 58 & 44,0 \\
\hline \multicolumn{3}{|l|}{ Pendidikan suami } \\
\hline Pendidikan dasar (SD + SLTP) & 60 & 45,5 \\
\hline Pendidikan lanjut (SLTA ke atas) & 72 & 54,5 \\
\hline \multicolumn{3}{|l|}{ Pekerjaan Ibu } \\
\hline Pegawai negeri sipil & 17 & 12,9 \\
\hline Swasta & 25 & 18,9 \\
\hline Ibu rumah tangga & 89 & 67,4 \\
\hline \multicolumn{3}{|l|}{ Pekerjaan suami } \\
\hline Petani & 42 & 31,8 \\
\hline Pegawai negeri & 22 & 16,7 \\
\hline Swasta & 68 & 51,5 \\
\hline \multicolumn{3}{|l|}{ Pendapatan keluarga } \\
\hline $\operatorname{Rp} 500.000,--\operatorname{Rp} 1.000 .000$ & 75 & 56,8 \\
\hline$>\operatorname{Rp} 1.000 .000,--\operatorname{Rp} 2.000 .000,-$ & 47 & 35,6 \\
\hline$>\operatorname{Rp} 2.000 .000,--\operatorname{Rp} 4.000 .000,-$ & 10 & 7,6 \\
\hline \multicolumn{3}{|l|}{ Pengeluaran pangan } \\
\hline$<\operatorname{Rp} 100.000,--\operatorname{Rp} 300.000$ & 26 & 9,7 \\
\hline$>\operatorname{Rp} 300.000,--\operatorname{Rp} 500.000,-$ & 69 & 52,3 \\
\hline$>\operatorname{Rp} 500.000,-$ & 37 & 28,0 \\
\hline \multicolumn{3}{|l|}{ Pengeluaran nonpangan } \\
\hline$<\operatorname{Rp} 100.000,--\operatorname{Rp} 300.000$ & 70 & 53,0 \\
\hline$>\operatorname{Rp} 300.000,--\operatorname{Rp} 500.000,-$ & 40 & 30,3 \\
\hline$>\operatorname{Rp} 500.000,-$ & 22 & 16,7 \\
\hline
\end{tabular}

jenis cacing Ascaris lumbricoides + Trichiuris trichiura dengan anemia adalah 4 orang $(66,7 \%)$ dan yang mengalami infeksi 2 jenis cacing Ascaris lumbricoides + Necator americanus dengan anemia sebanyak 1 orang $(100 \%)$.

Ditemukan hubungan bermakna antara infeksi 3 jenis cacing Ascaris lumbricoides + Trichiuris trichiura + Necator americanus dengan anemia ibu hamil $(p=0,018)$ dan jumlah ibu hamil yang positif terinfeksi 3 jenis cacing ini dengan anemia adalah 6 orang $(75 \%)$.
Hubungan antara kecacingan dengan kadar feritin ibu hamil

Hubungan antara infeksi kecacingan dengan kadar feritin ibu hamil dapat dilihat pada Tabel 3. Dari tabel tersebut diketahui bahwa tidak ada hubungan bermakna antara infeksi Ascaris lumbricoides maupun Trichiuris trichiura dengan kadar feritin, nilai $p$ masing-masing 0,17 dan 0,25 . Jumlah ibu hamil yang positif terinfeksi kecacingan Ascaris 
TABEL 2. Hubungan antara kecacingan dengan anemia ibu hamil

\begin{tabular}{|c|c|c|c|c|c|c|c|}
\hline \multirow{2}{*}{ Infeksi cacing } & \multicolumn{2}{|c|}{ Tidak anemia } & \multicolumn{2}{|c|}{ Anemia } & \multirow{2}{*}{ OR } & \multirow{2}{*}{ IK 95\% } & \multirow{2}{*}{$\mathbf{p}$} \\
\hline & $n$ & $\%$ & $\mathbf{n}$ & $\%$ & & & \\
\hline \multicolumn{8}{|c|}{ Ascaris lumbricoides } \\
\hline Negatif & 39 & 70,9 & 16 & 29,1 & 2,43 & $0,44-13,38$ & 0,36 \\
\hline Positif & 3 & 50.0 & 3 & 50.0 & & & \\
\hline Total & 42 & 68,9 & 19 & 31,1 & & & \\
\hline \multicolumn{8}{|c|}{ Trichiuris trichiura } \\
\hline Negatif & 39 & 70,9 & 19 & 29,1 & - & $0,19-0,43$ & 0,30 \\
\hline Positif & 0 & 0,0 & 1 & 100,0 & & & \\
\hline Total & 39 & 69,6 & 17 & 30,4 & & & \\
\hline \multicolumn{8}{|c|}{ Ascaris lumbricoides + } \\
\hline \multicolumn{8}{|c|}{ Trichiuris trichiura } \\
\hline Negatif & 39 & 70,9 & 16 & 29,1 & 4,87 & $0,81-29,32$ & 0,08 \\
\hline Positif & 2 & 33,3 & 4 & 66,7 & & & \\
\hline Total & 41 & 67,2 & 20 & 32,8 & & & \\
\hline \multicolumn{8}{|c|}{ Trichiuris trichiura + } \\
\hline \multicolumn{8}{|c|}{ Necator americanus } \\
\hline Negatif & 39 & 70,9 & 16 & 29,1 & - & $0,19-0,43$ & 0,30 \\
\hline Positif & 0 & 0,0 & 1 & 5,9 & & & \\
\hline Total & 39 & 69,6 & 17 & 30,4 & & & \\
\hline \multirow{2}{*}{\multicolumn{8}{|c|}{$\begin{array}{l}\text { Ascaris lumbricoides }+ \\
\text { Trichiuris trichiura }+ \text { Necator } \\
\text { americanus }\end{array}$}} \\
\hline & & & & & & & \\
\hline Negatif & 39 & 70,9 & 16 & 29,1 & 7,3 & $1,33-40,14$ & $0,02^{*}$ \\
\hline Positif & 2 & 25,0 & 6 & 75,0 & & & \\
\hline Total & 41 & 65,1 & 22 & 34,9 & & & \\
\hline
\end{tabular}

Keterangan:

* Signifikan ( $p<0,05 ;$ Fisher's exact test)

lumbricoides dengan kadar feritin $<12 \mu \mathrm{g} / \mathrm{dL}$ adalah 3 orang $(50 \%)$, namun tidak ada yang terinfeksi kecacingan Trichiuris trichiura dengan kadar feritin $<12 \mu \mathrm{g} / \mathrm{dL}$.

Ibu hamil yang positif terinfeksi 2 jenis cacing $A s-$ caris lumbricoides + Trichiuris trichiura dengan kadar feritin $<12 \mu \mathrm{g} / \mathrm{dL}$ sebanyak 2 orang(33,3\%). Hasil uji statistik membuktikan di antara infeksi 2 jenis cacing Ascaris lumbricoides + Trichiuris trichiura dengan kadar feritin ditemukan hubungan yang bermakna $(p=0,04)$. Namun demikian, antara infeksi 2 jenis cacing Ascaris lumbricoides + Necator americanus dengan kadar feritin tidak ditemukan hubungan yang bermakna $(p=$ 0,25 ) dan tidak ditemukan ibu hamil yang positif terinfeksi kedua jenis cacing tersebut dengan kadar feritin $<12 \mu \mathrm{g} / \mathrm{dL}$.

Antara infeksi 3 jenis cacing Ascaris lumbricoides + Trichiuris trichiura + Necator americanus dengan kadar feritin ditemukan hubungan yang bermakna $(p=0,007)$ dan terdapat 2 orang $(25 \%)$ yang positif terinfeksi 3 jenis cacing tersebut dengan kadar feritin $<12 \mu \mathrm{g} / \mathrm{dL}$.

\section{Hubungan antara malaria dengan anemia ibu hamil}

Pada penelitian ini, di antara 132 ibu hamil yang diperiksa darahnya, terdapat 11 orang $(64,7 \%)$ yang terinfeksi malaria dengan anemia. Hasil uji statistik membuktikan nilai $p=0,033$, sehingga disimpulkan ada hubungan bermakna antara malaria dengan anemia ibu hamil (Tabel 4).

\section{Hubungan antara malaria dengan kadar feritin ibu} hamil

Pada penelitian ini ditemukan hubungan bermakna antara malaria dengan kadar feritin ibu hamil $(p=0,0001)$. Hubungan antara malaria dengan kadar feritin ibu hamil dapat dilihat pada Tabel 5. Dari tabel tersebut diketahui bahwa di antara 132 ibu hamil yang diperiksa malaria, sebanyak 14 orang $(82,4 \%)$ positif terkena malaria dengan kadar feritin $<12 \mu \mathrm{g} / \mathrm{dL}$.

\section{BAHASAN}

\section{Karakteristik subjek penelitian}

Usia pertama kali menikah perlu mendapat perhatian. Di pedesaan, usia wanita yang menikah umumnya sangat muda, yaitu di bawah usia 15 tahun. Pada masa tersebut kematangan fisik, biologis, psikis belum terjadi, sehingga tak jarang terjadi perceraian atau kawin cerai (13). Usia melahirkan terlalu muda di bawah 20 tahun dan terlalu tua di atas 35 tahun akan meningkatkan risiko persalinan pada ibu.

Kekurangan darah karena kurang gizi merupakan penyebab utama penderitaan dan kematian ibu pada masa hamil. Penyakit ini terutama dialami oleh ibu yang memiliki banyak anak. Menurut Almatsier (14), ibu hamil dengan sakit anemia yang telah memiliki anak $\geq 4$ orang jumlahnya 3 kali lebih besar dibandingkan dengan ibu hamil yang jumlah keluarganya kecil.

Jumlah anggota keluarga mempengaruhi konsumsi zat gizi di dalam satu keluarga, sehingga mempengaruhi pula kesehatan anak-anak, ibu, dan keluarga (13). 
TABEL 3. Hubungan antara kecacingan dengan kadar feritin ibu hamil

\begin{tabular}{|c|c|c|c|c|c|c|c|}
\hline \multirow[t]{2}{*}{ Infeksi cacing } & \multicolumn{2}{|c|}{$\begin{array}{c}\text { Kadar feritin } \\
\geq 12 \mu \mathrm{g} / \mathrm{dL}\end{array}$} & \multicolumn{2}{|c|}{$\begin{array}{c}\text { Kadar feritin } \\
<12 \mu \mathrm{g} / \mathrm{dL}\end{array}$} & \multirow[t]{2}{*}{ OR } & \multirow[t]{2}{*}{ IK 95\% } & \multirow[t]{2}{*}{$\mathbf{p}$} \\
\hline & n & $\%$ & $\mathbf{n}$ & $\%$ & & & \\
\hline \multicolumn{8}{|l|}{ Ascaris lumbricoides } \\
\hline Negatif & 13 & 23,6 & 42 & 76,4 & 3,23 & $0,58-17,98$ & 0,17 \\
\hline Positif & 3 & 50,0 & 3 & 50,0 & & & \\
\hline Total & 16 & 26,2 & 45 & 73,6 & & & \\
\hline \multicolumn{8}{|l|}{ Trichiuris trichiura } \\
\hline Negatif & 13 & 23,6 & 42 & 76,4 & - & $0,14-0,38$ & 0,25 \\
\hline Positif & 1 & 7,1 & 0 & 0,0 & & & \\
\hline Total & 14 & 25,0 & 42 & 75,0 & & & \\
\hline \multicolumn{8}{|l|}{ Ascaris lumbricoides + } \\
\hline \multicolumn{8}{|l|}{ Trichiuris trichiura } \\
\hline Negatif & 13 & 23,6 & 42 & 76,4 & 6,4 & $1,06-39,39$ & $0,04^{*}$ \\
\hline Positif & 4 & 66,7 & 2 & 33,3 & & & \\
\hline Total & 17 & 27,9 & 44 & 72,1 & & & \\
\hline \multicolumn{8}{|l|}{ Trichiuris trichiura + } \\
\hline \multicolumn{8}{|l|}{ Necator americanus } \\
\hline Negatif & 13 & 23,6 & 42 & 76,4 & - & $0,14-0,38$ & 0,25 \\
\hline Positif & 1 & 100,0 & 0 & 0,0 & & & \\
\hline Total & 14 & 25,0 & 42 & 75,0 & & & \\
\hline \multicolumn{8}{|c|}{$\begin{array}{l}\text { Ascaris lumbricoides }+ \\
\text { Trichiuris trichiura }+ \text { Necator } \\
\text { americanus }\end{array}$} \\
\hline Negatif & 13 & 23,6 & 42 & 76,4 & 9,69 & $1,74-53,96$ & $0,01^{*}$ \\
\hline Positif & 6 & 75,0 & 2 & 25,0 & & & \\
\hline Total & 19 & 30,2 & 44 & 69,8 & & & \\
\hline
\end{tabular}

Keterangan:

${ }^{*}$ Signifikan $(p<0,05$; Fisher's exact test $)$

TABEL 4. Hubungan antara malaria dengan anemia pada ibu hamil

\begin{tabular}{|c|c|c|c|c|c|c|c|c|c|}
\hline \multirow[t]{2}{*}{ Infeksi malaria } & \multicolumn{2}{|c|}{ Tidak anemia } & \multicolumn{2}{|c|}{ Anemia } & \multicolumn{2}{|c|}{ Jumlah } & \multirow{2}{*}{ OR } & \multirow{2}{*}{ IK 95\% } & \multirow[b]{2}{*}{$\mathbf{p}$} \\
\hline & $\mathrm{n}$ & $\%$ & $n$ & $\%$ & $n$ & $\%$ & & & \\
\hline Tidak infeksi & 72 & 62,6 & 43 & 37,4 & 115 & 87,1 & 3,07 & $1,05-8,89$ & $0,03^{*}$ \\
\hline Infeksi & 6 & 35,3 & 11 & 64,7 & 17 & 12,9 & & & \\
\hline Total & 78 & 59,1 & 54 & 40,9 & 132 & 100 & & & \\
\hline
\end{tabular}

Keterangan:

* Signifikan $(p<0,05 ;$ Fisher's exact test)

Tingkat pendidikan, jenis pekerjaan, dan tingkat pendapatan akan mempengaruhi kebiasaan pemilihan makanan yang dikonsumsi keluarga. Makin tinggi pendidikan dan pekerjaan seseorang, secara tidak langsung akan mempengaruhi pemilihan makanan sehari-hari. Pendidikan ibu hamil di pedesaan sebagian besar hanya sampai tingkat SLTP, hanya sebagian kecil saja yang bisa mengenyam pendidikan lebih tinggi. Tingkat pendapatan akan menentukan pola makanan yang dibeli, baik jumlah maupun jenis makanan yang dibeli. Pola pembelanjaan makanan di antara kelompok kurang mampu dan mampu tercermin dari kebiasaan pengeluaran mereka. Di negaranegara miskin, sebagian besar pembelanjaan penduduk dialokasikan untuk makanan. Dengan kata lain, pendapatan merupakan faktor yang paling menentukan kuantitas dan kualitas makanan (15).

Ibu hamil dianjurkan untuk memeriksakan kehamilannya minimal 4 kali selama kehamilannya. Pada waktu pemeriksaan kehamilan, ibu hamil mendapatkan imunisasi tetanus toksoid untuk menghindari penyakit infeksi waktu persalinan, mendapatkan 90 tablet $\mathrm{Fe}$, serta pengukuran LILA untuk mengetahui keadaan gizi ibu. Jika ukuran LILA ibu hamil berada dalam daerah merah $(\leq 23,5 \mathrm{~cm})$, ibu tergolong kurus sekali dan dianjurkan makan banyak serta istirahat (16).

\section{Hubungan antara kecacingan dengan anemia ibu hamil}

Pada penelitian ini tidak diperoleh adanya hubungan bermakna antara infeksi cacing Ascaris lumbricoides dengan anemia pada ibu hamil. Hasil ini sejalan dengan penelitian Nurdiati (17) di Purworejo yang menyatakan bahwa tidak terdapat hubungan antara infeksi Ascaris lumbricoides dengan kadar hemoglobin ( $p=0,73$ dan $R R=0,96$ ) dan infeksi tersebut tidak berpengaruh terhadap anemia. Hal ini disebabkan pada saat penelitian, ibu hamil memperoleh gizi yang cukup. Cacing Ascaris lumbricoides yang habitatnya di dalam lumen usus halus manusia akan menyerap sari-sari makanan, namun tidak menyerap darah penderita, sehingga tidak berakibat langsung terhadap penurunan kadar hemoglobin. 
TABEL 5. Hubungan antara malaria dengan kadar feritin ibu hamil

\begin{tabular}{|c|c|c|c|c|c|c|c|c|c|}
\hline \multirow[t]{2}{*}{ Infeksi malaria } & \multicolumn{2}{|c|}{$\begin{array}{c}\text { Kadar feritin } \\
\geq 12 \mu \mathrm{g} / \mathrm{dL}\end{array}$} & \multicolumn{2}{|c|}{$\begin{array}{l}\text { Kadar feritin } \\
<12 \mu \mathrm{g} / \mathrm{dL}\end{array}$} & \multicolumn{2}{|c|}{ Jumlah } & \multirow[t]{2}{*}{ OR } & \multirow[t]{2}{*}{ IK $95 \%$} & \multirow[t]{2}{*}{$\mathbf{p}$} \\
\hline & $n$ & $\%$ & $\mathbf{n}$ & $\%$ & $n$ & $\%$ & & & \\
\hline Tidak infeksi & 91 & 79,1 & 24 & 20,9 & 115 & 87,2 & 17,69 & $4,70-66,61$ & $0,00^{*}$ \\
\hline Infeksi & 3 & 17,6 & 14 & 82,4 & 17 & 12,8 & & & \\
\hline Total & 94 & 71,2 & 38 & 28,8 & 132 & 100 & & & \\
\hline
\end{tabular}

Keterangan:

* Signifikan $(p<0,05 ;$ Fisher's exact test)

Antara infeksi Trichiuris trichiura dengan anemia juga tidak didapatkan hubungan yang bermakna. Penelitian ini sejalan dengan penelitian yang dilakukan oleh Nurdiati (17) di Purworejo yang melaporkan tidak ada hubungan bermakna antara infeksi Trichiuris trichiura dengan anemia $(p=0,93$; RR 1,15). Hal ini disebabkan sampel yang dianalisis jumlahnya sedikit, sehingga tidak berpengaruh terhadap kadar hemoglobin. Cacing Trichiuris trichiura di dalam tubuh manusia terutama hidup di sekum, yang dapat juga ditemukan pada kolon asendens. Pada infeksi berat, anak cacing tersebar di seluruh kolon dan rektum, kadang-kadang terlihat pada mukosa rektum yang mengalami prolapsus akibat mengejannya penderita sewaktu defekasi. Cacing ini memasukkan kepalanya ke dalam mukosa usus hingga terjadi trauma yang menimbulkan iritasi dan peradangan mukosa usus. Pada tempat pelekatan dapat menimbulkan pendarahan. Di samping itu, cacing ini menghisap darah hospesnya sehingga dapat menyebabkan anemia.

Infeksi 2 jenis cacing Ascaris lumbricoides + Trichiuris trichiura dan Ascaris lumbricoides + Necator americanus dengan anemia diketahui tidak terdapat hubungan yang signifikan. Hal ini mungkin disebabkan jumlah sampel yang terinfeksi dan yang dianalisis sedikit, sehingga tidak berpengaruh pada kadar hemoglobin.

Infeksi 3 jenis cacing Ascaris lumbricoides + Trichiuris trichiura + Necator americanus memiliki hubungan bermakna dengan anemia. Infeksi 3 jenis cacing ini mungkin disebabkan cacing Ascaris lumbricoides menghisap sari-sari makanan, cacing Trichiuris trichiura dan Necator americanus menghisap darah ibu hamil, sehingga berakibat anemia.

Kecacingan yang disebabkan oleh Necator americanus menyebabkan kehilangan darah secara perlahan-lahan. Hal ini disebabkan cacing tersebut hidup dalam rongga usus halus, tapi melekat dengan giginya pada dinding usus dan menghisap darah (16). Menurut Sadikin (18), seseorang yang terinfeksi kecacingan harus segera diobati, karena dapat menyebabkan pendarahan di usus dalam jangka waktu lama. Bila tidak segera diobati, cacing penghisap darah akan berkembang biak dalam jumlah besar, sehingga jumlah darah yang dihisap tiap hari lebih banyak dan pada akhirnya menyebabkan anemia.

Pada penelitian ini, jumlah prevalensi ibu hamil kecacingan dengan anemia (kadar hemoglobin < $11 \%$ ) sebesar 18,18\% dan anemia dengan kadar serum feritin $12 \mu \mathrm{g} / \mathrm{dL}$ sebesar $9,09 \%$. Angka prevalensi ini tergolong kecil, karena bukan merupakan masalah kesehatan. Menurut WHO cit. Stekette (8), kecacingan dapat disebut sebagai salah satu masalah kesehatan apabila angka prevalensi $\geq 30 \%$.

\section{Hubungan antara kecacingan dengan kadar feritin ibu hamil}

Dari hasil uji statistik secara bivariat didapatkan hasil tidak ada hubungan yang bermakna antara infeksi cacing Ascaris lumbricoides dengan kadar feritin pada ibu hamil $(p=0,17$; OR $=3,23$; IK 95\% = 0,58-17,98). Hal ini sejalan dengan penelitian yang dilakukan oleh Nurdiati (17) di Purworejo yang juga menyatakan tidak ada hubungan bermakna antara infeksi Ascaris /umbricoides dengan kadar feritin dengan nilai $p=0,81$ dan $R R=1,29$. Hal ini disebabkan jumlah sampel yang diperiksa positif Ascaris lumbricoides sedikit dan tidak jauh berbeda dengan penelitian ini (jumlah sampel ibu hamil dengan kecacingan dan anemia sebanyak 3 orang).

Hubungan yang tidak bermakna juga ditemukan antara infeksi cacing Trichiuris trichiura dengan kadar feritin $(p=0,30)$. Nurdiati (17) pada penelitiannya di Purworejo juga mendapatkan tidak ada hubungan yang bermakna antara infeksi Trichiuris trichiura dengan kadar feritin. Hal ini juga disebabkan jumlah sampel yang dianalisis sedikit (jumlah ibu hamil yang dinyatakan positif terkena kecacingan Trichiuris trichiura sebanyak 1 orang), sehingga tidak berpengaruh terhadap kadar feritin.

Hubungan yang bermakna ditemukan antara infeksi 2 jenis cacing Ascaris lumbricoides + Trichiuris trichiura dengan kadar feritin ( $p=0,04$; OR = 6,4; IK 95\% = 1,06-39,39). Dengan demikian anemia pada ibu hamil mungkin disebabkan oleh infeksi 2 jenis cacing, yaitu Ascaris lumbricoides yang menghisap sarisari makanan terutama karbohidrat dan protein, serta cacing Trichiuris trichiura yang menghisap darah secara lansung. Menurut Husaini (9), infestasi cacing menyebabkan banyak darah yang keluar, sehingga mengganggu jumlah cadangan zat besi di dalam tubuh, yaitu zat besi yang dikeluarkan lebih banyak daripada zat besi yang masuk. Kekurangan zat besi dalam tubuh dapat meningkatkan kerawanan terhadap penyakit infeksi.

Sebaliknya, hubungan antara infeksi 2 jenis cacing yaitu Ascaris lumbricoides + Necator americanus pada penelitian ini ditemukan tidak bermakna $(p=0,25)$. Hal ini juga disebabkan jumlah sampel yang terinfeksi dan yang dianalisis sedikit, sehingga tidak berpengaruh pada kadar feritin pada ibu hamil.

Infeksi 3 jenis cacing Ascaris lumbricoides + Trichiuris trichiura + Necator americanus pada penelitian ini diketahui 
memiliki hubungan yang bermakna dengan kadar feritin ibu hamil ( $p=0,007$; OR = 9,69; IK 95\%=1,74-53,96). Hal ini sesuai dengan pendapat Sastroamidjojo (19) yang menyatakan bahwa infeksi mempengaruhi status protein dan menyebabkan kekurangan protein akibat nafsu makan berkurang. Infeksi cacing dapat mengurangi absorbsi nitrogen apabila disertai dengan diare. Kerugian akibat kecacingan yang disebabkan oleh infeksi Ascaris lumbricoides antara lain: kehilangan karbohidrat sebesar 0,8 gram/hari, protein sebesar 0,19 gram/ hari, darah akibat cacing Trichiuris trichiura sebesar $0,2 \mathrm{~mL} /$ hari dan Necator americanus sebesar 0,005 mL/hari (16).

Infestasi cacing menyebabkan banyak darah yang keluar sehingga mengganggu keseimbangan zat gizi, yaitu zat gizi yang dikeluarkan lebih banyak daripada zat gizi yang masuk. Seseorang yang menderita defisiensi besi lebih mudah terserang mikroorganisme. Kekurangan besi oleh Husaini (9) dihubungkan dengan kerusakan kemampuan fungsional dan mekanisme kekebalan tubuh untuk menahan masuknya penyakit infeksi. Infeksi dapat mengganggu asupan makanan, penyerapan, serta penggunaan berbagai zat gizi termasuk zat besi. Kebutuhan besi meningkat pada kasus-kasus pendarahan kronis yang disebabkan oleh parasit seperti Necator americanus, Schistosoma sp., dan Trichiuris trichiura (20). Anemia tidak pernah menjadi penyebab utama dari suatu penyakit. Biasanya anemia selalu menjadi akibat sampingan dari keadaan patologis atau suatu penyakit tertentu. Makin rendah kadar hemoglobin, anemia yang diderita seseorang makin berat. Zat gizi yang paling berperan pada proses terjadinya anemia adalah besi. Defisiensi besi merupakan penyebab utama anemia gizi dibandingkan defisiensi zat gizi lain, seperti: folat, vitamin $B_{12}$, protein, vitamin, dan trace elements lainnya. Penyakit infeksi dan parasit merupakan salah satu penyebab anemia gizi besi. Dengan menanggulangi dan memberantas parasit diharapkan dapat meningkatkan status besi dalam tubuh. Upaya ini tentu harus dikuti dengan peningkatan konsumsi pangan yang seimbang dan beragam (9).

\section{Hubungan antara malaria dengan anemia ibu hamil}

Pada penelitian ini didapat hasil uji statistik adanya hubungan yang bermakna antara malaria dengan anemia pada ibu hamil ( $p=0,033$; OR = 3,07; IK 95\%=1,05-8,89). Hasil ini sejalan dengan penelitian Ngardita (21) di RSUD Jayapura dan Susanti (22) di Kabupaten Jayapura yang menyimpulkan bahwa ibu hamil yang terinfeksi malaria mempunyai risiko anemia lebih tinggi dibanding yang tidak anemia. Menurut Shulman (23) pada daerah endemis sedang malaria, wanita pada semua paritas memiliki BBLR yang subtansial dan anemia berat sebagai hasil infeksi malaria dan kehamilan. Suparman (24) menjelaskan bahwa malaria pada ibu hamil sangat merugikan, baik bagi ibu hamil sendiri maupun bagi janin yang dikandungnya. Hal ini disebabkan malaria dapat meningkatkan morbiditas dan mortalitas ibu dan janin. Akibat yang dapat ditimbulkan pada ibu hamil antara lain: anemia, malaria serebral, edema paru, gagal ginjal, bahkan kematian, sedangkan pada janin dapat menyebabkan abortus, BBLR (berat badan lahir rendah) dan kematian

Pada penelitian ini, prevalensi ibu hamil dengan anemia sebesar $10,61 \%$ dengan kadar hemoglobin $<11 \mathrm{~g}$, sedangkan prevalensi ibu hamil dengan kadar feritin $<12 \mu \mathrm{g} / \mathrm{dL}$ sebesar $10,61 \%$. Walaupun prevalensinya rendah, anemia pada ibu hamil dengan malaria dapat menyebabkan komplikasi. Komplikasi pada kehamilan karena infeksi malaria dapat mengakibatkan abortus, penyulit pada partus, anemia, hepatospenomegali, bayi dengan BBLR, gangguan fungsi ginjal, edema paru, hipokalemia, dan malaria kongenital (25).

Pada penderita malaria dengan siklus hidup aseksual dalam tubuh manusia, di dalam sel darah merah skizogoni dapat menyebabkan kerusakan eritrosit. Toksin malaria diduga menyebabkan gangguan eritrosit, sehingga eritrosit pecah saat melalui limpa penderita dan keluarlah parasit. Eritrosit dihancurkan tidak saja oleh pecahnya eritrosit yang mengandung parasit, tetapi juga oleh fagositogenisis eritrosit yang mengandung parasit dan yang tidak mengandung parasit, sehingga menyebabkan anemia anoreksia jaringan (26).

\section{Hubungan antara malaria dengan kadar feritin ibu hamil}

Hasil analisis bivariat penelitian ini menunjukkan adanya hubungan bermakna antara malaria dengan kadar serum feritin $(p=0,0001 ;$ OR $=17,69 ;$ IK 95\% = 4,7 - 66,6). Hasil ini sejalan dengan penelitian yang dilakukan oleh Ngardita (21) di RSUD Jayapura yang menyimpulkan bahwa terdapat hubungan bermakna antara malaria dengan kadar serum feritin $(p=0,000)$. Masawe et al. cit. Husaini (9) melaporkan bahwa orang yang kekurangan besi, sesudah diberi terapi besi menjadi sangat mudah terinfeksi malaria. Hal ini berbeda dengan penelitian yang dilakukan oleh Shankar cit. Ngardita (21) bahwa suplementasi besi berhubungan dengan beberapa pengukuran indeks malaria, akan tetapi hubungan antara keduanya relatif kecil dan tidak signifikan.

Anemia merupakan gejala yang paling sering dijumpai pada malaria. Kekurangan besi dapat menurunkan ketahanan tubuh menghadapi penyakit infeksi (malaria). Dalam keadaan AGB, kekebalan tubuh tidak berfungsi dengan baik. Hal ini menjadi penyebab orang yang kekurangan zat besi mudah sekali terkena penyakit infeksi. Sebaliknya, kelebihan zat besi seringkali digunakan oleh mikroorganisme untuk pertumbuhannya. Hal ini membuat ini membuat penyakit yang diderita makin parah (27).

Selama siklus hidup, bakteri membutuhkan zat gizi, termasuk zat besi untuk pertumbuhan dan produksi eksotoksin. Beberapa bakteri mengeluarkan sidophores untuk menangkap zat besi. Apabila kadar serum transferin dan laktoferin rendah, banyak besi bebas yang tersedia. Sidephores dari bakteri menangkap besi tersebut untuk pertumbuhan dan menghasilkan eksotoksin (9). 


\section{KESIMPULAN DAN SARAN}

\section{Kesimpulan}

Hasil penelitian ini menyimpulkan tidak ada hubungan antara kecacingan (Ascaris lumbricoides, Trichiuris trichiura, Ascaris lumbricoides + Trichiuris trichiura, Trichiuris trichiura + Necator americanus) dengan anemia, namun antara infeksi Ascaris lumbricoides + Trichiuris trichiura + Necator americanus dengan anemia didapatkan hubungan yang bermakna. Antara infeksi (Ascaris lumbricoides + Trichiuris trichiura dan Ascaris lumbricoides + Trichiuris trichiura + Necator Americanus) dengan kadar feritin juga ditemukan hubungan bermakna.

Ada hubungan antara malaria dengan anemia, begitu pula antara malaria dengan kadar feritin. Antara kadar feritin dengan anemia ditemukan hubungan yang bermakna.

\section{RUJUKAN}

1. Departemen Kesehatan RI. Program Penanggulangan Anemia Gizi pada Wanita Usia Subur (WUS). Jakarta: Direktorat Jenderal Pembinaan Kesehatan Masyarakat; 2003.

2. Linder MC. Nutritional Biochemistry and Metabolism. In: Jurnal Gizi Klinik Indonesia 2007; 3(3): 134-8.

3. Departemen Kesehatan RI. Pedoman Umum Gizi Seimbang Panduan untuk Petugas. Jakarta: Direktorat Jendral Pembinaan Gizi Masyarakat; 2002.

4. Departemen Kesehatan RI. Pedoman Operasional Penanggulangan Anemia Gizi di Indonesia. Jakarta: Direktorat Jendral Pembinaan Gizi Masyarakat; 1996.

5. Soefoewan MS. PengaruhAnemia Gizi pada lbu Hamil dan Bayi. In: Jurnal Gizi Klinik Indonesia 2007; 3(3): 134-8.

6. Departemen Kesehatan RI. Pedoman Pemberian Besi bagi Petugas. Jakarta: Direktorat Jenderal Pembinaan Gizi Masyarakat; 1996.

7. Departemen Kesehatan RI. Penanggulangan Anemia untuk Remaja Putri dan Usia Subur. Jakarta: Direktorat Jenderal Pembinaan Gizi Masyarakat; 1998.

8. Steketee. Infection and Inflamation: Pregnancy Nutrition and Parasitic Diseases. J Nutr 2003; 133(5): 1661S-1667S.

9. Husaini. Study Nutritional Anemia An Assesment of Information Compilation for Suporting and Formulating National Police and Program. Jakarta: Direktorat Bina Gizi, Departemen Kesehatan RI; 1989.

10. Dinas Kesehatan Provinsi Jambi. Hasil Survei Cepat Anemia. Jambi: Dinas Kesehatan Provinsi Jambi; 2003.

11. Dinas Kesehatan Kabupaten Batang Hari. Profil Kesehatan Kabupaten Batang Hari. Batang Hari: Dinas Kesehatan Kabupaten Batang Hari; 2004.

12. Lemeshow S, Hosmer D, Klar J. 1990. Adequacy of Sample Size in Health Studies. (Terjemahan) Pramono D. Yogyakarta: UGM Press; 1997. h. 1-11.

13. Sukarni M. Kesehatan Keluarga dan Lingkungan. Yogyakarta: Kanisius; 1994.

\section{Saran}

Ibu hamil yang tinggal di daerah endemis kecacingan perlu mendapatkan program pemberian obat cacing, pencegahan dan pengobatan malaria (profilaksis). Ibu hamil yang mengalami anemia gizi besi juga perlu mendapatkan program pemberian tablet besi dan penyuluhan gizi tentang makanan yang bergizi seimbang untuk ibu.

\section{Ucapan terima kasih}

Peneliti menyampaikan terima kasih yang sebesarbesarnya kepada Kepala Dinas Kesehatan Batang Hari, Kepala Puskesmas Kabupaten Batang hari, para enumerator, para responden, dan semua pihak yang membantu penelitian ini.

14. Almatsier S. Prinsip-prinsip Dasar Ilmu Gizi. Jakarta: Gramedia Pustaka Utama; 2004.

15. Berg A. Peranan Gizi dalam Pembangunan Nasional. Jakarta: Rajawali; 1986.

16. Departemen Kesehatan RI. Program Pemberian Obat Cacing di Era Desentralisasi. Jakarta: Dirjen PPM \& PL; 2001.

17. Nurdiati D. Studi Longitudinal Status Gizi dan Infestasi Parasit Usus Pada Ibu Hamil. Yogyakarta: Dirjen Dikti, Departemen Pendidikan dan Kebudayaan; 1997.

18. Sadikin M. Biokimia Darah. Jakarta: Widya Medika; 2001.

19. Sastroamidjojo. Simposium Masalah Penyakit Parasit dalam Program Pelayanan Kesehatan Menuju Masyarakat Bebas Parasit dan Sehat Gizi. Yogyakarta: Bagian IImu Penyakit Anak FK UI; 1980.

20. DeMaeyer. Pencegahan dan Pengawasan Anemia Defisiensi Besi. Jakarta; 1995.

21. Ngardita IR. Hubungan antara Asupan Gizi, Status Besi dan Berat Ringannya Infeksi Malaria pada Ibu Hamil di Rumah Sakit Umum Daerah Jayapura [tesis]. Yogyakarta: Universitas Gadjah Mada; 2004.

22. Susanti EG. Kontribusi Penyakit Malaria terhadap Prevalensi Anemi Ibu Hamil di Daerah Endemis Kabupaten Jayapura Propinsi Irian Jaya [tesis]. Yogyakarta: Universitas Gadjah Mada; 2001.

23. Shulman. Malaria in Pregnancy; Its Relevance Safe Motherhood Programmes, Department of Epydemiology and Public Health, London School Medicine and Hygiene. J Ann Trop Med Parasitol 1999; 93(1): S59-S66.

24. Suparman E. Malaria pada Kehamilan. Cermin Dunia Kedokteran 2005; (146): 19-25.

25. Harijanto PN. Malaria, Epidemiologis, Patogenesis, Manifestasi Klinis dan Penanganannya. Jakarta: EGC; 1999.

26. Gandahusada. Parasitoligi Kedokteran. Jakarta: Gaya Baru; 2003.

27. Wirakusumah ES. Perencanaan Menu Anemia Gizi Besi. Jakarta: Trubus Agriwidya; 1999. 